\title{
Financial role in supporting the sustainable development goals in ASEAN
}

\author{
Osangthammanont Anantachoke ${ }^{1^{*}}$ \\ ${ }^{1}$ International Institute for Trade and Development and Fiscal Policy Research Institutes \\ Staff, Thailand \\ *Corresponding author: aosang@ fispri.org
}

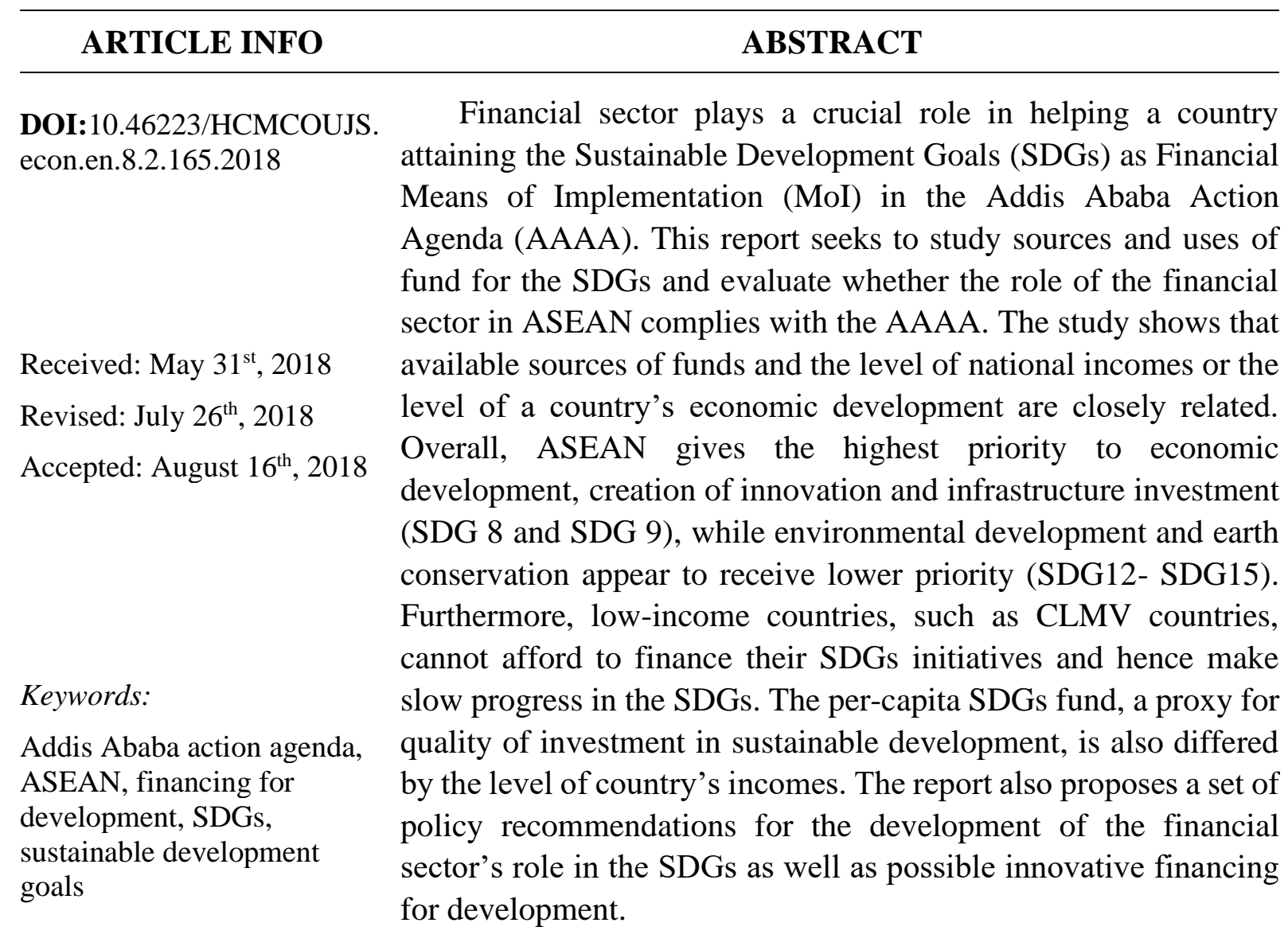

\section{Introduction}

The 17 sustainable development goals (SDGs) were adopted by the leaders of members of the United Nations (UN) during the UN summit in September 2015 (United Nations, 2014, 2015c, 2015e, 2016b). To achieve the SDGs by 2030, it is a tremendous challenge for ASEAN countries because sustainable development must balance all three dimensions: economy, society and environment. The financial sector clearly plays a critical role in achieving the SDGs because it can direct the necessary resources to the SDGs related activities. Insufficient financing can easily derail the progress in SDGs.

This study examines the role of the financial sector in promoting the SDGs in ASEAN. For each ASEAN country, the study investigates how the fund is sufficiently raised and properly 
allocated to the SDGs. To answer these questions, we compile a dataset on sources and uses of fund by country and then map the uses of fund to the SDGs. We also follow the United Nations' definition to link SDGs, cross-cutting issues in the Addis Agenda Action Agenda (AAAA) and 5Ps to propose an analytical framework for this study.

This study applies a set of indicators to make an assessment on the role of the financial sector in supporting the SDG advancement and investigate whether the role of the financial sector is consistent with the Addis Ababa Action Agenda (AAAA) (United Nations, 2015a, 2016a). The gap analysis is performed to understand individual ASEAN countries' SDGs situation, compared to the top country and the consistency between the fund allocation of Asian countries and their progress in the SDGs. Then, several synthesized development strategies in the financial sector are proposed as policy recommendations.

Our findings show that available sources of fund and the level of national incomes or the level of the country's economic development are closely related. Overall, ASEAN gives higher priority to economic development, creation of innovation and infrastructure investment (SDG8 and SDG9), followed by basic social needs and human development (SDG2-SDG4). The financial sector assessment reveals that ASEAN makes the most progress in the area of no poverty and clean water and sanitation as well as delivering social protection and the essential public for all. We also find that Singapore's financial sector is most likely to support the SDGs, while the rest of ASEAN needs to improve the role of their financial sector. The per-capita sustainable development fund, a proxy for quality of investment in sustainable development, is also differed by the level of country's incomes. Singapore has invested heavily in the SDGs and become a successful leader in sustainable development in ASEAN. Based on a holistic approach, our financial sector development strategies for Thailand and ASEAN are threepronged: (1) Access to finance strategy (2) Capacity building and competitiveness enhancement strategy and (3) Social and environment strategy.

The rest of this paper is organized as follows. The methodology and data used in this study will be explained in section 2 . Next, section 3 discusses the highlighted findings of the study. Then, section 4 proposes key policy priorities for achieving the SDGs in Thailand and ASEAN. Lastly, we draw the conclusion in section 5.

\section{Methodology and data}

This study starts with defining the scope of the financial sector for further analysis. Then, we examine the role of the financial sector in sustainable development using the Addis Abba Action Agenda (AAAA). We analyze the sources and uses of fund available in each ASEAN country and how these countries direct their fund to satisfy the sustainable development goals (the SDGs). Next, we evaluate the role of the financial sector for the SDGs. We also conduct a gap analysis to determine the difference between the current situation and the targets of the SDGs and the disparity between the current role of financial sectors and the ideals proposed by the AAAA. Based on the gap analysis, we devise a strategy to improve the role of the financial sector in the SDGs for Thailand and ASEAN. 


\section{Definition of the financial sector}

To scope our analysis better, we adopt the definition of the financial sector presented in Financial Mean of Implementation (MOI), part of the AAAA. The financial sector can be classified into 3 groups: (1) Domestic public resources, (2) Domestic and international private business and finance and (3) International development cooperation (United Nations, Economic and Social Commission of Asia and the Pacific (ESCAP), 2015a, 2015b).

Domestic public resources can be channeled through government budget, tax policies and government-owned financial institutions or specialized financial institutions (SFIs). Domestic public resources are considered an integral part for driving sustainable economic growth and creating macroeconomic stability. Moreover, they are the most important sources of fund for policy implementation. Sources of fund from government include government budget, tax revenue, and government financial institutions. Domestic and international private business and finance have several available channels including commercial banks and other financial institutions, securities exchange, foreign direct investment (FDI), remittance from workers abroad and philanthropists. Private enterprises are considered as an important vehicle to drive production, innovation, economic growth and job creation. Furthermore, the longterm domestic and international investments of private enterprises are significant for sustainable development. Since this sector has the largest source of fund, it has much potential to finance the SDGs in the future.

By contrast, international development cooperation is usually available through multinational development banks and international development agencies, generally in the forms of Official Development Assistance (ODA), i.e., concession loan, grant, or technical assistance. The fund available from this group depends on the economic situation of the ODA partners. Therefore, the size of fund is more limited and more uncertain.

\section{Analysis of the Use and Source of Fund for SDGs in ASEAN}

In this analysis, we are interested to know how the ASEAN countries raise their funds. We also want to examine how and how much these countries allocate these funds to achieve the SDGs. To do so, we need to compile a dataset containing the sources and uses of fund for each individual ASEAN country.

\section{Source of Fund Estimation}

To estimate the sources of fund for each country, we use 3-year average (2013-2015) data or the latest annual data available, pertaining to the government budget, loans from government's SFIs, loans from commercial banks, capital from the stock exchange, FDI, and ODA. The average data should reduce the impact of year-to-year fluctuation in data. Similarly, the uses of fund are estimated from the comparable sources of data.

Government data comes from individual ASEAN countries' budgetary data, excluding general administrative expenses, salary and wages of government officers, debt repayment and miscellaneous spending. Therefore, it mainly consists of an investment budget. Loans from SFIs and commercial banks are computed by a change in outstanding loans. New equity raised 
in the stock exchange can be estimated by either change in total equity of listed companies or change in market capitalization, depending on data availability. Thailand, Cambodia, Lao PDR and Myanmar will follow the former approach of new equity estimation, while the rest of ASEAN countries will use the latter one (Asian Development Bank, 2017b). We use annual data of net inflow of FDI and ODA directly.

\section{Use of Fund Estimation}

Based on sources of fund data, we then map the allocation of fund by sector to the SDGs. We track government budget allocation for the SDGs from objectives of budget usage. Likewise, we employ data on outstanding loans by sector of SFIs and commercial banks as their uses of fund. For new equity, we use the latest available data on the share of listed companies by sector in the stock exchange. In the case of FDI and ODA, their data on allocation by sector is used.

\section{Data on sources and uses of fund}

Government data can be found in the National Economic and Social Development Plan or ADB's Key Indicators for Asia and the Pacific 2016 (Asian Development Bank, 2016). Data of SFIs comes from their financial statements and the Bank of Thailand, while that of commercial banks is collected from their financial statements. Change in total equity of listed companies is available from the stock exchange in Thailand, Cambodia, Lao PDR and Myanmar, while a change in market capitalization comes from World Development Indicators (Bank Negara Malaysia, 2015, 2016; World Federation of Exchanges database, 2016). We use FDI data from ASEAN Foreign Direct Investment Statistics Database, prepared by the ASEAN Working Group on International Investment Statistics (WGIIS) (Association of Southeast Asian Nations, 2015a, 2015b; Department of Statistics Malaysia, 2016). For ODA, we rely on data from various sources such as ADB (Asian Development Bank, 2016, 2017a), the World Bank (World Bank Group, 2013, 2014h) and OECD (OECD, 2007, 2015, 2017).

In this study, data on budget allocation, SFI loans by sector and commercial bank loans by sector come from the same sources as those of fund data. On the other hand, data on new equity by sector is available from the stock exchange and Data Stream 2013. FDI data by sector is provided by investment promotion agencies or the like of each country. We can find data on the allocation of ODA by sector from ADB, the World Bank and OECD as well.

\section{Evaluation of the Role of Financial Sector for the SDGs}

As the financial sector can play a crucial role in SDGs progress, this study wants to make an assessment of whether ASEAN's financial sector supports the SDGs implementation. Moreover, we want to examine if the role of the financial sector complies with the framework of the AAAA. A country that makes good progress in the SDGs is supposed to have a wellfunctioned financial sector as well as good supporting policies. Therefore, the role of the financial sector along with other related policies should be more supportive in a country with good progress in the SDGs. In other words, this is an indirect approach to make an assessment of the role of financial sector. 
We adapt the methodology employed in Bertelsmann Stiftung and Sustainable Development Solutions Network (SDSN) (2016) to evaluate the progress of the SDGs in ASEAN. The report was prepared by the Bertelsmann Stiftung and Sustainable Development Solutions Network (SDSN) (2016) and Sustainable Development Solutions Network to help countries realize where they currently stand with regards to progress in the SDGs in 2015. To do so, the report uses a set of 64 indicators to capture the progress in 17 SDGs, which are subsequently reclassified into 7 groups according to the AAAA's cross-cutting issues. For each indicator, data will be normalized by transform it linearly into a scale of 0 to 1 using the following formula.

$$
x^{\prime}=\frac{x-\operatorname{lower}(x)}{\text { upper }(x)-\operatorname{lower}(x)}
$$

Where $x^{\prime}$ denotes to the rescaled value, $x$ denotes an original value of indicator, upper $(x)$ denotes the upper bound of the indicators, which is the best value, and finally, lower $(x)$ denotes lower bound of the indicator, which is the worst value after dropping the bottom $2.5 \%$ as outliners. Then the rescaled score will be multiplied by 100 to make a scale of 0 to 100 . This score will represent "the average initial placement" of the country, between the worst and best performance. For simplicity, we will use the best performance or score of 100 as the target for each SDG. For each SDG, we will use at least one indicator forthe assessment. In the case of having more than one indicator for one SDG, we will use a simple average of those indicators to represent the current achievement on each SDG.

Next, the SDGs are transformed into the 7 cross-cutting issues in the Addis Ababa Action Agenda and use scores on the SDGs to calculate the scores for each cross-cutting issue in the same manner. Lastly, the overall SDG Index and the overall AAAA Index of a country can be computed by taking a simple average of the country scores on each of the 17 SDGs and on each of cross-cutting issues respectively. The dataset used for computing the SDG index and the AAAA index is readily available at the report website (United Nations, 2015c). Concerning the different economic circumstances and level of development among ASEAN countries, this study compares sets of indicators employing data on the basis of per capita term while the use of all types of funds is evaluated by the percentage of each country's GDP. The rationale involves the relative reflection of funding mobilization for the sustainable development of each country. Countries with different levels of development may financially set different policy priorities and demands for economic, social, and environmental development to be consistent with the SDGs. In other words, lower-income countries might prioritize the budget and fund to reduce poverty and hunger, while higher-income countries might mobilize their funds towards more quality goals such as peace, equality, environment, partnership, and social aspects. Moreover, grouping SDGs into 5Ps (People, Prosperity, Planet, Peace and Partnership) is useful when we explain our results

\section{The Linkage between the SDGs and the Addis Ababa Action Agenda}

The policy implementations ultimately need sufficient sources of fund in order to drive successful SDG projects. The Addis Ababa Action Agenda (AAAA) has 3 targets which are: 
1) To follow the commitments and progress of the 2002 Monterrey Consensus and the 2008 Doha Declaration in each country; 2) To adjust the funding method for sustainable development and the actions under the Universal Post-2015 Development Agenda; and 3) To emphasize and upgrade the following methods of development funding progress. However, it includes new challenges such as the crisis of the economy as well as financial, natural crisis, and epidemic of virus, etc. The funding should be a corporation of stakeholders including the government and private sector, which are the main targets of Cross-Cutting Issues from the AAAA.

The AAAA also includes the following Action Areas: 1) the Financial sector for sustainable development, 2) International Trade as an Engine for Development, 3) Debt and Debt Sustainability, 4) Addressing Systemic Issues and 5) Science, Technology, Innovation and Capacity Building. The financial sector is mainly divided into 3 parts, which are 1) Domestic Public Resources, 2) Domestic and International Private Business and Finance and 3) International Development Cooperation. The analysis finds that the AAAA emphasizes every Cross-Cutting Issues while the Sustainable Development Corporation is as well an important part of success target under cross-cutting issues. Moreover, the study also suggests that SDG10 and SDG17 should be included as a part of every Cross Cutting Issue (see Table 1).

\section{Table 1}

The linkage between Cross-Cutting issue of The Addis Ababa Action Agenda and Sustainable Development Goals (SDGs)

\begin{tabular}{|c|c|c|c|}
\hline $\begin{array}{l}\text { Cross- } \\
\text { Cutting } \\
\text { Issue }\end{array}$ & Definition & $\begin{array}{c}\text { Sustainable } \\
\text { Development } \\
\text { Goals (SDGs) }\end{array}$ & Definition \\
\hline \multirow[t]{9}{*}{ AAAA1 } & \multirow{9}{*}{$\begin{array}{l}\text { Delivering social } \\
\text { protection and essential } \\
\text { public services for all }\end{array}$} & SDG1 & No Poverty \\
\hline & & SDG3 & Good Health and Well-Being \\
\hline & & SDG4 & Quality Education \\
\hline & & SDG6 & Clean Water and Sanitation \\
\hline & & SDG7 & Affordable and Clean Energy \\
\hline & & SDG8 & Decent Work and Economic Growth \\
\hline & & SDG10 & Reduced Inequalities \\
\hline & & SDG11 & Sustainable Cities and Communities \\
\hline & & SDG17 & Partnerships for The Goals \\
\hline \multirow[t]{3}{*}{ AAAA2 } & \multirow{3}{*}{$\begin{array}{l}\text { Scaling up efforts to enc } \\
\text { hunger and malnutrition }\end{array}$} & SDG2 & Zero Hunger \\
\hline & & SDG10 & Reduced Inequalities \\
\hline & & SDG12 & $\begin{array}{l}\text { Responsible Consumption } \\
\text { and Production }\end{array}$ \\
\hline
\end{tabular}




\begin{tabular}{|c|c|c|c|}
\hline $\begin{array}{l}\text { Cross- } \\
\text { Cutting } \\
\text { Issue }\end{array}$ & Definition & $\begin{array}{c}\text { Sustainable } \\
\text { Development } \\
\text { Goals (SDGs) }\end{array}$ & Definition \\
\hline & & SDG17 & Partnerships for The Goals \\
\hline \multirow[t]{3}{*}{ AAAA3 } & \multirow{3}{*}{$\begin{array}{l}\text { Establishing a new } \\
\text { forum to bridge the } \\
\text { infrastructure gap }\end{array}$} & SDG9 & $\begin{array}{l}\text { Industry, Innovation and } \\
\text { Infrastructure }\end{array}$ \\
\hline & & SDG10 & Reduced Inequalities \\
\hline & & SDG17 & Partnerships for The Goals \\
\hline \multirow[t]{3}{*}{ AAAA4 } & \multirow{3}{*}{$\begin{array}{l}\text { Promoting inclusive and } \\
\text { sustainable } \\
\text { industrialization: }\end{array}$} & SDG9 & $\begin{array}{l}\text { Industry, Innovation and } \\
\text { Infrastructure }\end{array}$ \\
\hline & & SDG10 & Reduced Inequalities \\
\hline & & SDG17 & Partnerships for The Goals \\
\hline \multirow[t]{3}{*}{ AAAA5 } & \multirow{3}{*}{$\begin{array}{l}\text { Generating full and } \\
\text { productive employment } \\
\text { and decent work for all } \\
\text { and promoting MSMEs: }\end{array}$} & SDG8 & Decent Work and Economic Growth \\
\hline & & SDG10 & Reduced Inequalities \\
\hline & & SDG17 & Partnerships for The Goals \\
\hline \multirow[t]{7}{*}{ AAAA6 } & \multirow{7}{*}{$\begin{array}{l}\text { Protecting our } \\
\text { ecosystems for all: }\end{array}$} & SDG2 & Zero Hunger \\
\hline & & SDG10 & Reduced Inequalities \\
\hline & & SDG12 & $\begin{array}{l}\text { Responsible Consumption } \\
\text { and Production }\end{array}$ \\
\hline & & SDG13 & Climate Action \\
\hline & & SDG14 & Life Below Water \\
\hline & & SDG15 & Life on Land \\
\hline & & SDG17 & Partnerships for The Goals \\
\hline \multirow[t]{4}{*}{ AAAA7 } & \multirow{4}{*}{$\begin{array}{l}\text { Promoting peaceful and } \\
\text { inclusive societies }\end{array}$} & SDG5 & Gender Equality \\
\hline & & SDG10 & Reduced Inequalities \\
\hline & & SDG16 & Place and Justice Strong Institutions \\
\hline & & SDG17 & Partnerships for The Goals \\
\hline
\end{tabular}

Notes: AAAAi is Cross-Cutting issue $\mathrm{i}$ of the Addis Ababa Action Agenda, where $\mathrm{i}=1,2, \ldots, 7$ and

SDGj is Sustainable Development Goals (SDGs) where $\mathrm{j}=1,2, \ldots, 17$

Sources: United Nations (2016) and the Research Team

The Linkage between the SDGs and 5Ps

The linkage between areas of critical importance 5 terms (5Ps) and the SDGs is not formally explained by the United Nations, so that the scope of 5Ps would vary depending on each organization. Hence, this study divides 5Ps and the SDGs following Dhlamini (2016), 
which People is associated with SDG1- SDG6; Prosperity is associated with SDG7 - SDG11; Planet is associated with SDG12- SDG15; Peace is associated with SDG16; and Partnership is associated with SDG17.

\section{Gap Analysis}

The gap analysis shows how far we are now from our goal. We take two approaches to perform the gap analysis. The first approach takes the best performance for each SDG as a goal for that SDG. Therefore, the gap will be simply estimated by the difference between 100 and the country's score for each SDG and overall SDG. The second approach looks at the gap or discrepancy between the current progress of the SDGs and the allocation of funds for the SDGs. For ASEAN countries, a country score, which is lower ASEAN average score for each SDG, should match with less allocation of fund. That is, the larger discrepancy between the SDGs performance and fund allocation should imply a larger gap in this analysis.

\section{Results and discussion}

The highlighted results from the study mainly emphasize 2 issues: the role of the financial sector in sustainable development in ASEAN, and evaluation and gap analysis of ASEAN financial sector in accordance with the Addis Ababa Action Agenda.

\section{The Role of the Financial Sector in Sustainable Development in ASEAN}

The performance of mobilizing and financing for the SDGs in ASEAN countries may depend on many factors including level of development, level of the overall education of its citizens, number of population, and annual incomes of a country. In this study, 10 ASEAN countries are divided into 3 groups using GNI per capita to assess the sources of fund structure potential to finance the SDGs. The study shows that available sources of fund and the level of national incomes or the level of the country's economic development are closely related. That is, higher incomes usually imply a wider range of financing options. The first group, which has annual GNI per capita below \$3,000 consisting of Cambodia, Lao PDR, Myanmar, and Vietnam (CLMV), generally exhibits the main sources of fund largely came from government budget (30$70 \%$ share of total source of fund) followed by commercial banks and FDI respectively. The second group of ASEAN middle-income countries, consisting of Malaysia, Thailand, Philippines, and Indonesia, mostly shows the source of fund structure which mainly came from government budget followed by listed companies and commercial banks respectively. The third group implies higher income per capita indicates different sources of fund structure. As presented by the sophisticated financial system, the most important source of fund in Singapore comes from the listed companies. However, Brunei heavily relies on government budget ( $87 \%$ share) for its sustainable development. That is, Brunei is a special case. Despite her high incomes, her capital market is less advanced.

Regarding the analysis of the use of fund on the SDGs in ASEAN Countries, overall ASEAN give higher priority to economic development, creation of innovation and infrastructure investment (SDG8 and SDG9, i.e., Prosperity), followed by basic social needs and human development (SDG2 - SDG4, i.e., People). Environmental development and earth conservation appear to receive lower priority (SDG12 - SDG15, i.e., Planet). For disaggregated use of fund in ASEAN, distribution of government spending on the SDGs in ASEAN mostly 
ensure the basic need of citizen particularly on SDG3 - SDG4 (i.e., People), accounting for approximately 20-50\% of total use of fund in ASEAN, followed by economic development and infrastructure investment particularly on SDG8 - SDG9 (i.e., Prosperity), or 10-40\% share of the total (World Bank Group, 2016c). The overall funding from commercial bank loans in ASEAN essentially contributes to economic development (SDG8 and SDG9, i.e., Prosperity), accounting for $70-100 \%$ of the total. Finally, the overall funds in ASEAN received from ODA providing are highly distributed to SDG8 and SDG9 (i.e., Prosperity), accounting for 60-70\% of the total, followed by SDG1 - SDG4 (i.e., People) (Aidflows, 2014; Alesina \& Dollar, 2000; The Charities Aid Foundation, 2014, 2015; UNITAID, 2017). However, in order to maximize positive contribution to the SDGs, it is vital to view and monitor the effectiveness of financing intended for the SDGs in terms of per-capita flows. The finding examined is also consistent across the region as the higher income countries, Singapore and Brunei, allocate the largest per capita funding in 2016 of $\$ 41,133$ and $\$ 27,372$ for the SDGs respectively. The middle-income countries, Malaysia, Thailand and Philippines, involve per-capita SDG spending of $\$ 3,706$ $\$ 1,534$ and $\$ 1,198$ respectively, followed by Vietnam, Indonesia, Lao PDR, Cambodia and Myanmar which have per-capita spending contributed to the SDGs of $\$ 1,067 \$ 892 \$ 499 \$ 473$ and $\$ 380$ respectively.

Evaluation and Gap Analysis of ASEAN Financial Sector in accordance with The Addis Ababa Action Agenda

The evaluation results of policy implementation and overall performance of financing for development in ASEAN using indicators from SDG Index \& Dashboards: A Global Report (July 2016), and then adjusted in accordance with AAAA, indicates that the SDG1 (No poverty) is the best-performed SDG in ASEAN (highest average scores of 87.50, or the lowest policy gap of 12.50), signifying that most population in ASEAN generate income above $\$ 1.90$ per day, as a result of fair access to basic needs and resources provided by the government (See Table 2). The top three performers of SDG1 are Singapore (scores of 100), Thailand (scores of 99.91), and Malaysia (scores of 99.59). By contrast, the study shows SDG17 (Partnerships for the goals) is the lowest performance on ASEAN average (lowest average scores of 18.12, or the highest gap of 81.88), implying insufficient government resources or inefficient distribution to service public activities properly, such as an increase in the level of international partnership, support to achieve national development plan, and encouragement of international trade.

The evaluation results of policy implementation and overall performance of financing for development in ASEAN by cross-cutting issues of AAAA indicate that AAAA1 points out the highest average scores of 61.88 (the lowest policy gap of 38.12), implying that most ASEAN countries mainly emphasize policy implementation regarding improvement on quality of life (see Table 3). In the opposite, AAAA3, as well as AAAA4, seem to receive the lowest policy priority as represented by the lowest evaluation scores of 34.37 for both cross-cutting issues (or the highest policy gap of 65.63). This signifies by low average scores of related indicators including quality of overall infrastructure, mobile broadband subscriptions, internet use, R\&D researchers and R\&D expenditures (Asian Development Bank, 2014; UNCDF, 2016a, 2016b, 2016c, 2017; World Bank Group, 2014a, 2014b, 2014c, 2014e, 2014f, 2014g, 2014i, 2015, 2016a, 2016b). 


\section{Table 2}

Evaluation results of policy implementation and overall performance of financing for development in ASEAN by SDG

\begin{tabular}{|c|c|c|c|c|c|c|c|c|c|c|}
\hline SDGs & Cambodia & Indonesia & a Lao PDR & Malaysia & Myanmar & Philippines & Singapore & Thailand & Vietnam & Avg. \\
\hline SDG1 No Poverty & 91.05 & 76.86 & 56.40 & 99.59 & - & 80.92 & 100.00 & 99.91 & 95.30 & 87.50 \\
\hline SDG2 Zero Hunger & 52.70 & 51.77 & 54.21 & 64.89 & 55.58 & 53.11 & 70.92 & 57.88 & 66.08 & 58.57 \\
\hline SDG3 Good Health and Well-Being & 52.50 & 53.74 & 46.23 & 69.73 & 44.82 & 57.77 & 85.26 & 62.96 & 64.18 & 59.69 \\
\hline SDG4 Quality Education & 68.26 & 55.63 & 64.42 & 62.08 & 53.97 & 66.44 & 89.55 & 64.55 & 72.35 & 66.36 \\
\hline SDG5 Gender Equality & 51.12 & 62.08 & 49.02 & 53.68 & 63.61 & 62.90 & 68.71 & 66.01 & 72.42 & 61.06 \\
\hline SDG6 Clean Water and Sanitation & 61.52 & 76.10 & 72.41 & 97.09 & 78.87 & 83.03 & 100.00 & 94.69 & 89.21 & 83.66 \\
\hline SDG7 Affordable and Clean Energy & 17.15 & 61.59 & 33.37 & 84.75 & 40.15 & 67.28 & 89.50 & 77.38 & 70.68 & 60.20 \\
\hline $\begin{array}{l}\text { SDG8 Decent Work and Economic } \\
\text { Growth }\end{array}$ & 55.47 & 63.76 & 62.57 & 63.97 & 55.30 & 55.50 & 74.55 & 72.00 & 57.50 & 62.29 \\
\hline $\begin{array}{l}\text { SDG9 Industry, Innovation and } \\
\text { Infrastructure }\end{array}$ & 12.50 & 21.60 & 15.30 & 46.67 & 2.52 & 17.27 & 80.50 & 35.61 & 32.62 & 29.40 \\
\hline SDG10 Reduced Inequalities & 71.80 & 66.20 & 69.92 & 44.80 & - & 53.37 & - & 62.94 & 73.02 & 63.15 \\
\hline $\begin{array}{l}\text { SDG11 Sustainable Cities and } \\
\text { Communities }\end{array}$ & 66.44 & 48.81 & 52.40 & 85.12 & 26.78 & 69.30 & 82.77 & 64.06 & 53.08 & 60.97 \\
\hline $\begin{array}{l}\text { SDG12 Responsible } \\
\text { Consumption and Production }\end{array}$ & 0.00 & 46.05 & 44.34 & 40.92 & 46.79 & 46.49 & 86.71 & 42.34 & 34.03 & 43.08 \\
\hline SDG13 Climate Action & 51.76 & 84.49 & 75.80 & 72.35 & 74.52 & 84.17 & 82.16 & 60.40 & 65.28 & 72.33 \\
\hline SDG14 Life Below Water & 20.28 & 42.83 & - & 44.99 & 31.76 & 53.60 & 32.17 & 50.89 & 33.87 & 38.80 \\
\hline SDG15 Life on Land & 30.18 & 29.76 & 39.06 & 14.04 & 46.50 & 34.99 & 46.63 & 55.80 & 29.76 & 36.30 \\
\hline $\begin{array}{l}\text { SDG16 Place and Justice Strong } \\
\text { Institutions }\end{array}$ & 39.79 & 59.43 & 52.96 & 57.86 & 43.38 & 52.56 & 80.49 & 49.22 & 52.66 & 54.26 \\
\hline SDG17 Partnerships for The Goals & 19.04 & 8.69 & 17.56 & 26.00 & 8.27 & 12.97 & 25.07 & 29.29 & 16.17 & 18.12 \\
\hline Avg. of all SDGs & 44.80 & 53.49 & 50.37 & 60.50 & 44.85 & 55.98 & 74.69 & 61.53 & $\mathbf{5 7 . 5 4}$ & \\
\hline
\end{tabular}

Source: Data analysis result of the research 


\section{Table 3}

Evaluation results of policy implementation and overall performance of financing for development in ASEAN by AAAA

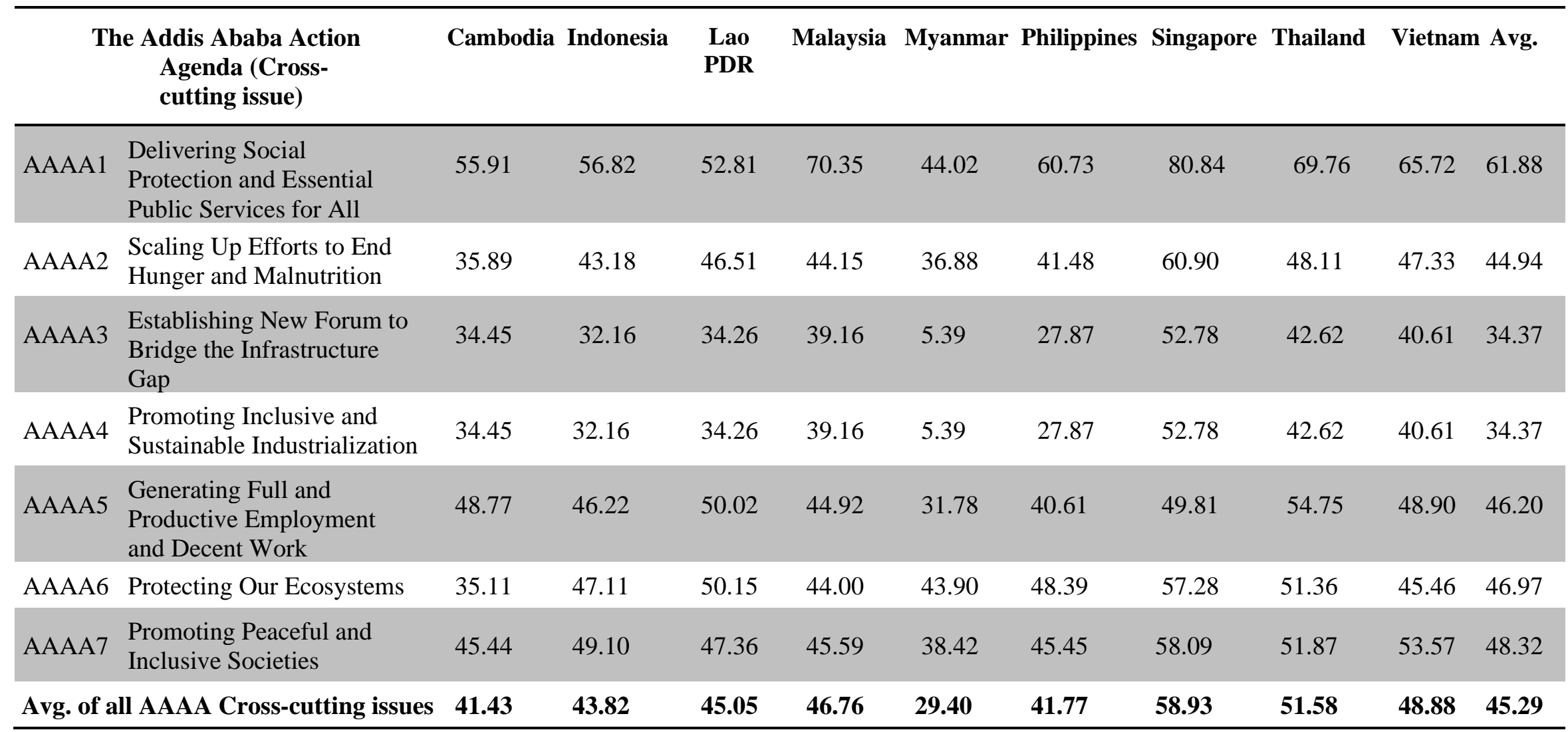

Source: Data analysis result of the research 


\section{Key policy priorities for achieving the SDGs in Thailand and ASEAN}

The findings of this study can be further used to formulate a financial sector development strategy for Thailand and ASEAN. We can apply the SWOT analysis and TOWS matrix to derive key strategies while setting priorities based on the gap in SDGs achievement and relevance to the national development plan (Bank Islam, 2017; UNDP, 2016a, 2016b).

Based on the above analysis, we can formulate a set of financial sector development strategies for Thailand and ASEAN, which looks beyond the financial sector. Since the study concentrates on a whole ecosystem of the financial sector, the derived strategies are threepronged: (1) Access to finance strategy (2) Capacity building and competitiveness enhancement strategy and (3) Social and environment strategy.

\section{Highest-priority strategies}

Access to finance strategy: This strategy aims to lower barriers to finance. For Thailand, the financial institution should be incentivized to finance targeted sectors and the interest rate spread should be managed properly for SMEs. The capital market such as stock exchange should be promoted as a reliable source of funds for SDGs. Financial literacy and access to IT infrastructure and equipment are the foundation of a new financial platform, which promises to lower cost and better access to financial services. Moreover, financing innovation is a must. In the case of Thailand, philanthropist's donation has tremendous potential.

For ASEAN, we should focus on cooperation among ASEAN countries. They can set up ODA for lower-income ASEAN countries and attract new ODA to the region (McGillivray, 2003). Furthermore, ASEAN should encourage the use of Fintech in the business sector.

Capacity building and competitiveness enhancement strategy: This strategy takes a longterm view of financial sector development. Essentially, the capacity of financing of a country is determined by its level of development. Thailand should shift her focus high quality and high tech products and attract more innovation-and-high-tech investment. More importantly, Thailand must pursue the capacity building of her human resources as well as moral consciousness and social responsibility. Cultural and natural tourism could be the future of Thai tourism. Moreover, Thailand should leverage on her cooperation with other countries to improve her R\&D activities.

ASEAN should support the development of technology and innovation in the region. Also, ASEAN should build on existing intra-regional trade and investment to create a region-wide value chain, which benefits all participants. Capacity building of human resources, SMEs promotion and extensive urbanization should be among ASEAN's top priorities.

Social and environment strategy: This strategy serves as a stabilizer of the financial sector development strategy. Sustainable development must strike the balance between economic, social and environmental dimensions. Thailand should provide sufficient medical services to all groups. Private sector participation in large-scale investment and liberalized and transparent government procurement will help prevent corruption. Furthermore, Thailand should promote environmental protection and the use of alternative and renewable energies.

Similarly, ASEAN should deter corruption through liberalized and transparent government procurement and public-private partnership. ASEAN should raise awareness of sustainable 
production and consumption. Finally, ASEAN should encourage the use of alternative energies in place of fossil fuels.

\section{Innovative Financing}

Since the criteria for the investment of public and private sectors are different, the private sector emphasizes on the return and risk of investment. For most cases of countries in ASEAN, the financial resource of the private sector is normally larger than those of governments and ODA combined. Thus, innovative financing (UNDP, 2012; United Nations, 2009) may help to induce more funding for sustainable development from the private sector (Ketkar \& Ratha, 2009; Girishankar, 2009). For instance, Diaspora bond (Rambarran \& Ramlakhan, 2014; Reuters, 2016) can induce a new group of investors which are people working in foreign countries; Education bond can help families to save their money for their children education. Moreover, the government can reduce public debt burden by using innovative financing such as Infrastructure Fund (Asian Development Bank, 2015), Commodity and Stabilization Fund, as well as pooled institutional fund to enable economies of scale, and further adoption among smaller institutions, integrated structured financing solutions with a focus on more "investable sectors" - energy, infrastructure and water, agriculture and food, and healthcare.

For the private sector, innovative financing may be in various approaches (World Economic Forum, 2017). For example, private businesses join the project of RED products to improve their organization images of social responsibility, non-financial return. Another approach is reducing cost of the private sector via Fintech such as Mobile-Banking, BranchlessBanking Blockchain, and Crowdfunding. The third approach is toreduce risk and increase investor confidence via guarantees from reliable organizations such as Social Impact Bonds (RAND, 2015) issued by the United Nations. The last approach is to target special type of retail investors, called "impact investors" (C-Change and Sustainable Development Goals Charter, 2016), in order to mobilizing retail-oriented impact capital, such as Green bond (World Bank Group, 2008, 2014d) or Sustainability bond (Sustainalytics, 2015), issuing to raise fund for reducing impacts of the climate change problem.

Moreover, at present social enterprises (Bugg-Levine, Kogut, \& Kulatilaka, 2012), organizations directly involved in the sale of goods and services to a market, but that also has specific social objectives that serve as its primary purpose, may also play an important role in providing financial benefit with social goals to communities. The good examples include AfriKids, an organization established under Convention on the Rights of the Child, Alive and Kicking that manufactures sports balls to provide balls for children, create jobs for adults and promote health education through sport, ADUNA, an Africa-inspired health food brand and social business, and SocialGiver as they convert spare service capacity into social impact.

\section{Policy recommendations}

This study proposes the following policy recommendations to all stakeholders involving SDG development.

(1.) ASEAN members need to invest for sustainable development continuously, provided that the role of the financial sector is always important. The related measures include: 1) 
integration of a sustainable development plan and a country's long-term development strategy; 2) fiscal management skill development improve fiscal management skills in revenue collection, revenue and expenditure forecast, financing planning, ODA utilization and budgetary control; and 3) promotion of financing for sustainable development from private sector and international cooperation.

(2.) According to the framework of the Addis Ababa Action Agenda, SDG development should be holistic to increase the role of the financial sector. The related measures include: 1) promotion of all stakeholders' participation in the making of a country's development strategy from the beginning; 2) success rate improvement of policy implementation setting clear targets of country development with measurable KPIs properly reflecting the development targets; 3 ) efficiency improvement of relevant policy implementation executives and staffs; and 4) business sector's value chain development focusing on value-added creation through business operation efficiency improvement, demand-driven technology creation or application, branding and marketing.

(3.) The public sector needs to expand its income base since the public domestic resource is the most important source of fund for financing SDG projects, especially in the social and environmental aspects. The related measures include: 1) promotion of more rigorous budget review process; 2) efficiency enhancement in government's expenditure and procurement; 3) tax-based expansion and new tax imposition consistent with global development; 4) trade liberalization in goods and services to allow for more competition in business; 5) promotion of technology usage in both public and private sectors; and 6) promotion of Thai entrepreneurs to take part in the global value chain while building their own value chain.

(4.) The government should encourage blended finance by giving incentives to private sector and cooperate with foreign countries and international organizations. The related measures include: 1) cooperation among government, non-profit organizations and domestic and international private funds; and 2) credibility and incentive enhancement for private investment relating to sustainable development.

(5.) Financing for sustainable development for any financial sector must determine priority and objective clearly. Project monitoring and evaluation process are necessary. The related measures include: 1) establishment of an agency responsible for sustainable development goals; and 2) establishment of Joint Committee among public, private, and social sectors responsible for sustainable development.

(6.) Due to the fact that source of fund options and financial allocation of each ASEAN member are different depending on the income and development level of each country, each country should decide on the appropriate source of fund for that country. The related measures include: 1) development of financial and capital markets including related infrastructures; 2) enhancement of fundraising ability of private enterprises and standards including management, selling, marketing, research and development, and accounting; 3) promotion of financial literacy to citizen across countries; and 4) promotion of foreign investors to invest in stocks and bonds markets. 
(7.) Since there is limitation for financial cooperation among ASEAN members for sustainable development, and the members have different needs, financial cooperation should not affect the sustainable development plan of each country. Each country needs investment in economic, social, and environmental developments continuously to improve capability and competitiveness of that country. The related measures include: 1) promotion of knowledge exchange among ASEAN countries; 2) full support for financial cooperation which already realizedin ASEAN countries, such as ASEAN Financial Integration Framework (AIFF) and The ASEAN Blueprint 2025; 3) promotion of sustainable development corporation among ASEAN countries, which share common interest, such as Neighbouring Countries Economic Development Cooperation Agency in CLMV countries; 4) explicit inclusion of sustainable development in main goals of the next ASEAN Blueprint consistent with the promises stated by the leaders of ASEAN countries (ASEAN Secretariat, 2015 \& Asian Development Bank, 2013).

\section{Conclusion}

To achieve the SDGs in 2030, the financial sector definitely plays a critical role in supporting this agenda as a crucial mean of implementation. This study examines whether the role of the financial sector in ASEAN supports the advancement of the SDGs. The findings of this study show that each ASEAN country raises and allocates fund to SDGs differently. Moreover, it indicates that the role of the financial sector for SDGs in each ASEAN country is indeed important, but the effectiveness of the financial sector is different.

The nature of fundraising and allocation is varied by the stage of development or level of income. A more developed country with higher income usually has more options for financing and hardly needs innovative financing. Moreover, the more developed country allocates their fund to build the nation's long-term competitiveness as well as the environment and has higher quality of investment (higher per capita spending) for the SDGs. For ASEAN, we clearly see that Singapore, which is the most developed country, fits the above description very well. On the other end of the spectrum, we have CLMV countries, especially for Cambodia, Lao PDR and Myanmar, which are completely opposite. Indonesia, Malaysia, Philippines and Thailand are somewhere in the middle, while Brunei is a special case in ASEAN - a high - income country with an underdeveloped financial system. This study shows that sustainable development is an ongoing process. ASEAN countries must continue to invest in the SDGs. Domestic public resources is always the most important financial sectors for SDGs as it can overcome market failures in financial, social, and environmental SDGs, while private sector can provide more financing to economic SDGs as economy grows. While the long-term financial sector development depends on the country's competitiveness, we need to attract more financing for the SDGs from the private sector and the government should provide incentives to align the interest of the public and private sectors. This is where innovative financing is much needed. Finally, due to the different background of ASEAN countries, it is not easy to have cooperation in financing for development when each country has to compete for own resources. The existing financial cooperation is designed to fully support the SDGs. Therefore, there is much work to be done to have meaningful financial cooperation for the SDGs in ASEAN. 


\section{References}

Aidflows. (2014). Beneficiary view, sources and uses of ODA. Retrieve February 10, 2018, from http://www.aidflows.org/PL_Beneficiary_View.pdf

Alesina, A., \& Dollar, D. (2000). Who gives foreign aid to whom and why? Journal of Economic Growth, 5(1), 33-63. doi:10.1023/A:1009874203400

ASEAN Secretariat. (2015). ASEAN integration report 2015. Retrieve February 10, 2018, from https://asean.org/storage/2015/12/ASEAN-Integration-Report-2015.pdf

Asian Development Bank. (2013). The road to ASEAN financial integration. Retrieve February 21, 2018, from https://www.adb.org/sites/default/files/publication/30202/road-aseanfinancial-integration.pdf

Asian Development Bank. (2014). Asia SME finance monitor 2014. Retrieve February 17, 2018, from https://www.adb.org/sites/default/files/publication/173205/asia-sme-financemonitor2014.pdf

Asian Development Bank. (2015). Local currency bonds and infrastructure finance in ASEAN+3. Retrieve February 07, 2018, from https://www.adb.org/sites/default/files/publication/167313/local-currency-bonds-andinfrastructure-finance-asean-3.pdf

Asian Development Bank. (2016). Key indicators for Asia and the Pacific 2016. Retrieve February 12, 2018, from https://www.adb.org/sites/default/files/publication/204091/ki2016.pdf

Asian Development Bank. (2017a). Asian development bank and Thailand: Fact sheet. Retrieve March 10, 2018, from https://www.adb.org/sites/default/files/publication/27802/tha_1.pdf

Asian Development Bank. (2017b). Thailand funding information. Retrieve March 11, 2018, from https://www.adb.org/

Association of Southeast Asian Nations. (2015a). ASEAN statistical yearbook 2015. Retrieve February 15, 2018, from https://www.aseanstats.org/wpcontent/uploads/2016/10/ASEAN-Statistical-Yearbook-2015_small_size.pdf

Association of Southeast Asian Nations. (2015b). Foreign direct investment net inflows, intraand extra-ASEAN. Retrieve April 10, 2018, from https://asean.org/storage/2015/09/Table252.pdf

Bank Islam. (2017). $11^{\text {th }}$ Malaysian plan (2016-2020). Retrieve February 10, 2018, from http://www.bankislam.com.my/home/assets/uploads/11MP_210515.pdf

Bank Negara Malaysia. (2015). Liquidity coverage ratio. Retrieve February 22, 2018, from https://www.bnm.gov.my/guidelines/01_banking/04_prudential_stds/Liquidity_Coverage _Ratio.pdf

Bank Negara Malaysia. (2016). Monthly statistical bulletin. Retrieve February 10, 2018, from https://www.bnm.gov.my/index.php?ch=en_publication\&pg=en_msb\&ac=238\&en

Bertelsmann Stiftung. \& Sustainable Development Solutions Network (SDSN). (2016). SDG index \& dashboards: A global report. Retrieve April 13, 2018, from https://www.bertelsmann-

stiftung.de/fileadmin/files/BSt/Publikationen/GrauePublikationen/SDG_Index_Dashboard _full.pdf 
Bugg-Levine, A., Kogut, B., \& Kulatilaka, N. (2012). A new approach to funding social enterprises. Retrieve February 19, 2018, from Harvard Business Review website: https://hbr.org/2012/01/a-new-approach-to-funding-social-enterprises

C-Change and Sustainable Development Goals Charter. (2016). Building highways to SDG investing: Invitation to collaborate on a Dutch sustainable development investing agenda. Retrieved March 10, from https://static1.squarespace.com/static/582981ddebbd1ad7f34681b6/t/5899acd5c534a5036 aeada0c/1486466378381/Building+Highways+to+SDG+Investing+PDF.pdf

Department of Statistics Malaysia. (2016). Press release statistics of foreign direct investment in Malaysia, 2015. Retrieved March 18, 2018, from https://www.dosm.gov.my/v1/index.php?r=column/pdfPrev\&id=Yjg2V01ORDBBbGRY ZW11cmwxM2wzQT09

Dhlamini, L. (2016). Integrating agenda 2030 for Sustainable Development Goals (SDGs) into regional and national development plans and strategies. Retrieved March 23, 2018, from Republic of South Africa website: https://www.za.undp.org/content/south_africa/en/home/presscenter/articles/2017/01/20/int egrating-agenda-2030-for-sustainable-development-goals-sdgs-into-regional-andnational-development-plans-and-strategies-by-lindiwe-dhlamini.html

Girishankar, N. (2009). Innovative development finance: From financing sources to financial solutions. Washington, DC: World Bank.

Ketkar, S., \& Ratha, D. (2009). Innovative financing for development. Washington, DC: The International Bank for Reconstruction and Development.

McGillivray, M. (2003). Aid effectiveness and selectivity: Integrating multiple objectives into aid allocations. DAC Journal, 4(3), 23-36.

OECD. (2007). Subsidy reform and sustainable development: Political economy aspects, OECD sustainable development studies. Retrieve April 09, 2018, from https://www.cbd.int/financial/fiscalenviron/g-subsidyreform-oecd.pdf

OECD. (2015). Agriculture sector flow by official development assistance. Retrieve May 10, 2018, from https://www.oecd.org/

OECD. (2017). Aid at a glance by Thailand. Retrieve May 14, 2018, from http://www.oecd.org

Rambarran, J., \& Ramlakhan, P. (2014). Diaspora bonds and Caribbean economic development. In S. Sahoo, \& B. Pattanaik (Eds.), Global diasporas and development. New Delhi, India: Springer.

RAND (2015). Evaluating the world's first social impact bond. Retrieve May 16, 2018, from https://www.rand.org/randeurope/research/projects/social-impact-bonds.html

Reuters. (2016). Countries look to draw expatriate cash with 'diaspora bonds'. Retrieved January 20, 2018, from Reuters website: https://www.reuters.com/article/us-emerging-bondsdiaspora/countries-look-to-draw-expatriate-cash-with-diaspora-bonds-idUSKCNOXE0ID

Sustainalytics. (2015). Development bank of Japan: Sustainability bond framework overview and $\begin{array}{lllll}\text { opinion. } & \text { Retrieve } & \text { May } & \text { 2018, from }\end{array}$ https://www.dbj.jp/pdf/ir/credit/sri/sustainability/001_opinion.pdf 
The Charities Aid Foundation. (2014). World giving index 2014, a global view for giving trends. Retrieve April 29, 2018, from https://www.cafonline.org/docs/default-source/about-uspublications/caf_wgi2014_report_1555awebfinal.pdf

The Charities Aid Foundation. (2015). World giving index 2015, a global view for giving trends. Retrieve April 11, 2018, from https://www.cafamerica.org/wpcontent/uploads/1755A_WGI2015_Report_WEB_V2_FINAL.pdf

UNCDF. (2016a). Amret awarded grant to expand women's financial inclusion through digital finance family. Retrieve May 22, 2018, from https://www.uncdf.org/article/1663/amretawarded-grant-to-expand-womens-financial-inclusion-through-digital-finance-migration

UNCDF. (2016b). UNCDF provides support to Banque Franco Lao Ltd. in moving into digital financing of distribution chains to benefit small women-run businesses. Retrieve May 12, 2018, from from https://www.uncdf.org/

UNCDF. (2016c). Vi-Viet e-wallet by LienViet PostBank (Vietnam) to have 500,000 women financially included by 2018. Retrieve January 10, 2018, from https://www.uncdf.org/article/1652/vi-viet-e-wallet-by-lienvietpostbank-vietnam-to-have500000-women-financially-included--migration

UNCDF. (2017). Using digital gamification for enhancing financial literacy in Myanmar. Retrieve February 23, 2018, from https://www.uncdf.org/article/1689/using-digitalgamification-for-enhancing-financial-literacy-in-myanmar-migration

UNDP. (2012). Innovative financing for development: A new model for development finance?. Retrieve February 14, 2018, from https://www.undp.org/content/undp/en/home/librarypage/povertyreduction/development_cooperationandfinance/innovative_financingfordevelopmentanew modelfordevelopmentfinance.html

UNDP. (2016a). Development finance for the 8th national socio-economic development plan and the sustainable development goals in Lao PDR. Retrieve March 26, 2018, from https://www.undp.org/content/dam/rbap/docs/meetTheSDGs/Laos\%20PDR\%20DFA\%20 -\%20Development $\% 20$ Finance\%20for\%20the\%208th\%20Nat\%20SocioEconomic\%20Dev\%20Plan\%20and\%20the\%20SDGs.pdf

UNDP. (2016b). UNDP support to the implementation of the sustainable development goals. Retrieve March 16, 2018, from https://hivlawcommission.org/wpcontent/uploads/2017/07/SDG-3-Health.pdf

UNITAID. (2017). Unitaid invests in better ways to prevent, diagnose and treat diseases. Retrieve February 20, 2018, from https://unitaid.org/\#en

United Nations. (2009). Innovative financing for development, The I-8 Group, Leading Innovative Financing for Equity [L.I.F.E.], December 2009. Retrieve January 12, 2018, from https://www.un.org/esa/ffd/wp-content/uploads/2014/09/InnovativeFinForDev.pdf

United Nations. (2014). Sustainable development goals, proposal, open working group of the general assembly on sustainable development goals, 2014. Retrieve June 10, 2017, from https://sustainabledevelopment.un.org/content/documents/1579SDGs\%20Proposal.pdf

United Nations. (2015a). Addis Ababa Action Agenda on the third international conference on financing on development (Addis Ababa Action Agenda). Retrieve February 18, 2018, from https://unctad.org/meetings/en/SessionalDocuments/ares69d313_en.pdf 
United Nations. (2015b). From decisions to actions, report of the secretary-general of UNCTAD to UNCTAD XIV. Retrieve March 06, 2018, from https://unctad.org/en/PublicationsLibrary/unctad_xivd1_en.pdf

United Nations. (2015c). Indicators and a monitoring framework for the sustainable development goals, the leadership council of the sustainable development solutions network. Retrieve February 28, 2018, from https://sustainabledevelopment.un.org/content/documents/2013150612-FINAL-SDSNIndicator-Report1.pdf

United Nations. (2015d). Sendai framework for disaster risk reduction 2015 - 2030, UNISDR. Retrieve April 15, forom https://sustainabledevelopment.un.org/content/documents/2157sendaiframeworkfordrren. pdf

United Nations. (2015e). The millennium development goals report 2015. Retrieve May 25, 2018, from https://www.un.org/millenniumgoals/2015_MDG_Report/pdf/MDG\%202015\%20rev\%20 (July\%201).pdf

United Nations. (2016a). Addis Ababa Action Agenda, Monitoring commitments and actions, inaugural report 2016 - Inter-agency task force on financing for development. Retrieve March 14, 2018, from https://www.un.org/esa/ffd/wpcontent/uploads/2016/03/Report_IATF-2016-full.pdf

United Nations. (2016b). The sustainable development goals report 2016. Retrieve July 10, 2017, from https://unstats.un.org/sdgs/report/2016/The\%20Sustainable\%20Development\%20Goals\% 20Report\%202016.pdf

United Nations Conference on Trade and Development. (UNCTAD) (2014). The least developed countries report 2014 growth with structural transformation: A post-2015 development agenda. Retrieve May 23, 2018, from https://unctad.org/en/PublicationsLibrary/ldc2014_en.pdf

United Nations, Economic and Social Commission of Asia and the Pacific (ESCAP). (2015a). Financing for transformation: From agenda to action on sustainable development in Asia and the Pacific. Retrieve May 30, 2018, from https://www.unescap.org/sites/default/files/Financing-for-Transformation-Final.pdf

United Nations, Economic and Social Commission of Asia and the Pacific (ESCAP). (2015b). Sustainable development financing: Perspectives from Asia and the Pacific. Retrieve April 11, 2018, from https://www.unescap.org/sites/default/files/0Sustainable\%20Development\%20Financing-Perspectives\%20from\%20AP.pdf

United Nations Economic and Social Council. (2012). The 2012 triennial review. Retrieve February 05, 2018, from https://assets.publishing.service.gov.uk/government/uploads/system/uploads/attachment_d ata/file/225401/CoRWM_triennial_review_2012.pdf

World Bank Group. (2008). What are green bonds? Retrieve March 30, 2018, from http://documents1.worldbank.org/curated/en/400251468187810398/pdf/99662-

REVISED-WB-Green-Bond-Box393208B-PUBLIC.pdf 
World Bank Group. (2013). Financing for development post-2015. Retrieve February 02, 2018, from http://pubdocs.worldbank.org/en/932281485530446820/Financing-for-developmentpub-10-11-13web.pdf

World Bank Group. (2014a). Automated Teller Machines (ATMs): Per 100,000 adults. Retrieve April 14, 2018, from https://data.worldbank.org/indicator/FB.ATM.TOTL.P5?locations=GH

World Bank Group. (2014b). GDP per unit of energy use (PPP per kg of oil equivalent). Retrieve February 12, 2018, from https://data.worldbank.org/indicator/EG.GDP.PUSE.KO.PP

World Bank Group. (2014c). Government expenditure on education, total (\% of GDP). Retrieve February 13, 2018, from https://data.worldbank.org/indicator/SE.XPD.TOTL.GD.ZS

World Bank Group. (2014d). Growing the green bond market to finance a cleaner, resilient world. Retrieve February 24, 2018, from https://www.cfainstitute.org/en/research/cfadigest/2014/04/growing-the-green-bond-market-to-finance-a-cleaner-resilient-worlddigest-summary

World Bank Group. (2014e). Health expenditure, public (\% of GDP). Retrieve April 12, 2018, from https://data.worldbank.org/indicator/SH.XPD.CHEX.GD.ZS

World Bank Group. (2014f). Percentage of adults owning an account through a mobile money provide. Retrieve February 03, 2018, from https://www.worldbank.org/

World Bank Group. (2014g). PPP investment in infrastructure. Retrieve February 15, 2018, from https://www.worldbank.org/

World Bank Group. (2014h). Revenue excluding grants: \% of GDP. Retrieve June 12, 2017, from https://data.worldbank.org/indicator/GC.REV.XGRT.GD.ZS

World Bank Group. (2014i). Tax revenue: \% of GDP. Retrieve June 17, 2017, from https://data.worldbank.org/indicator/GC.TAX.TOTL.GD.ZS

World Bank Group. (2015). Commercial bank branches per 100,000 adults. Retrieve February 07, 2018, from https://data.worldbank.org/indicator/FB.CBK.BRCH.P5

World Bank Group. (2016a). Percent of firms with a female top manager. Retrieve May 10, 2018, from https://www.indexmundi.com/facts/indicators/IC.FRM.FEMM.ZS

World Bank Group. (2016b). Private participation in infrastructure database. Retrieve February 10, 2018, from https://openknowledge.worldbank.org/handle/10986/9423

World Bank Group. (2016c). The worldwide governance indicators, 2016 update. Retrieve April 13, 2018, from https://www.worldbank.org/

World Economic Forum. (2017). Balancing financial stability, innovation, and economic growth. Retrieve June 20, 2017, from http://www3.weforum.org/docs/IP/2017/FS/WEF_Whitepaper_FSIEG.pdf

World Federation of Exchanges database. (2016). Market capitalization of listed domestic companies. $\quad$ Retrieve June 29, 2017, from https://data.worldbank.org/indicator/CM.MKT.LCAP.CD 